\title{
Efficiency of Integrated Nutrient Management to Improve Soil Health Growth Parameters and Yield Attributes of Rice (Oryza sativa L.) Var:Bpt-5204
}

\author{
Dudekula Sarmas Vali*, Arun Alfred David, Narendra Swaroop and Tarence Thomas
}
Department of Soil Science and Agricultural Chemistry, Sam Higginbottom University Of Agriculture, Technology and Sciences, Naini, Prayagraj, (U.P.), India.

*Corresponding author

\section{A B S T R A C T}

Ke y w o r d s

Rice straw, Integrated nutrient management, Sustainable agriculture, Poultry manure, Soil health parameters, etc.

Article Info

Accepted:

17 September 2020 Available Online: 10 October 2020
Combination of organic and inorganic sources of nutrients is necessary for sustainable agriculture that can ensure food production with high quality area under the rice cultivation is high but the productivity is low due to various interaction factors like the imbalance usage of fertilizers is one of the main factors responsible for the low productivity and also the continuous use of inorganic fertilizers resulted in declining of soil fertility. The present investigation on field experiment of "Efficiency of Integrated Nutrient Management to improve soil health growth parameters and yield attributes in Rice (Oryza sativa L.)" was carried out in Kharif during 2019 in sandy loamy soil with organic matter, available NPK and $\mathrm{pH}$, EC are recorded as $0.52 \%, 280.24 \mathrm{~kg} \mathrm{ha}^{-1}, 35.50 \mathrm{~kg}$ $\mathrm{ha}^{-1}, 175.14 \mathrm{~kg} \mathrm{ha}^{-1}, 7.33,0.04 \mathrm{dSm}^{-1}$ respectively at the research farm of SSAC, NAI, SHUATS Prayagraj. The experiment consisted of 9 treatment combinations and which were replicated thrice and laid out in a randomized block design. The results showed that progressive increase the growth (plant height $(\mathrm{cm})$ and number of tillers) and yield (panicle length, number of seeds per panicle, grain yield and straw yield) in application of $\mathrm{T}_{7^{-}}$ (@50\% RDF+ Poultry Manure @ $5 \mathrm{t} \mathrm{ha}^{-1}$ ) in rice were to be found the best treatment combinations.

\section{Introduction}

The green revolution had gradually turned into a 'greedy revolution' as evident in the indiscriminate use of inorganic inputs to attain higher productivity (Swaminathan, 2002). Rice (Oryza sativa L.) is a tillering plant belongs to the family Gramineae Chromosome no. of rice is $2 n=24$. Rice production in India is an important part of the national economy. India is the world's 2 nd largest producer after china accounting for $22 \%$ of the world's rice production.

Rice is one of the three most important food grain crops in world, forms the staple diet of 2.7 billion people. Its cultivation is of immense importance to food security of Asia, 
where more than $90 \%$ of the global rice is produced and consumed. Rice belongs to the genus Oryza, sub tribe oryzineae of the family Gramineae. There are 21 recognized species in genus Oryza. Rice production in India during 2019-20 is 117.47 million tonnesit is higher by 9.67 million tonnes than the average five years production and the rice cultivating area in India is $43.97 \mathrm{~m} \mathrm{ha}^{-1}$ (The economics time magazine 2019). Rice is grown in Uttar Pradesh during kharif season from June to October/November. Uttar Pradesh is the second largest rice producing state after west Bengal with the production of 11.62 million tonnes and the rice cultivated land in Uttar Pradesh is $5.86 \mathrm{~m} \mathrm{ha}^{-1}$ (The economics time magazine 2019).

Uttar Pradesh is one of the major rice growing state in the country. It accounts about 14.54 percent of total rice production in the country (2018-19) all types of soils are mostly suited for its cultivation. the traditional rice farming systems in India broadly include wetland \{lowland and upland\} system. the life cycle can be divided into 3 important phases, i.e. vegetative, reproductive and ripening.

Rice is an important and extensively cultivated food crop which feeds more than half of the world's population. in Asia alone, more than 2 billion people obtain 60 to 70 percent of their energy intake from rice and its derivatives per capita requirement of rice in India is $130 \mathrm{~kg}$ per annum (FAO 2017) and Rice is a nutritious crop and it produces 32-59 percent of the dietary energy and 25-40 percent of dietary protein in 39 countries. consumption of $100 \mathrm{~g}$ cooked rice can supply 111 kilo calories energy, $0.9 \mathrm{~g}$ total fat, 43 milli gram potassium, $23 \mathrm{~g}$ carbohydrates, 1.8 $\mathrm{g}$ dietary fibre and $0.4 \mathrm{~g}$ sugar India has the largest area among rice growing countries and it stands second in production next to China (Udhyakumar and Ramasamy, 2016).

\section{Materials and Methods}

The experiment was conducted on the research farm of department of soil science and agricultural chemistry, NAINI, SHUATS, Prayagraj. it is on the bank of Yamuna river, the experimental site was located in the subtropical region with $25.43^{\circ} \mathrm{N}$ latitude, $81.84^{0}$ E longitude and $98 \mathrm{~m}$ above from the MSL. the soil of experimental area falls in order of Inceptisols and soil is a alluvial in nature, texture sandy loam, it consist of 9 treatments which were replicated thrice and laid out in a randomised block design. The treatment combinations are $\mathrm{T}_{1^{-}}$(@ absolute control), $\mathrm{T}_{2}-(@ 100 \% \mathrm{RDF}), \mathrm{T}_{3}-$ (@ 50\% RDF + FYM@5 t ha $\left.^{-1}\right), \quad \mathrm{T}_{4}-(@ 50 \% \mathrm{RDF}+$ Vermicompost@5 tha $\left.\mathrm{ha}^{-1}\right), \mathrm{T}_{5}-(@ 50 \% \mathrm{RDF}+$ Rice straw@5 t ha $\left.{ }^{-1}\right), \mathrm{T}_{6^{-}}(@ 25 \% \mathrm{RDF}+$ Vermicompost@2.5 tha ${ }^{-1}+$ FYM @2.5 tha ${ }^{-1}$ + Rice Straw @2.5 tha $\left.{ }^{-1}\right), \mathrm{T}_{7}-(@ 50 \% \mathrm{RDF}+$ Poultry manure@5 t ha $\left.{ }^{-1}\right), \mathrm{T}_{8}-(@ 25 \% \mathrm{RDF}$ +FYM@ $@ 2.5$ tha $^{-1}+$ PSB @ $1 \mathrm{Kgha}^{-1}$ +Vermicompost @ 2.5 tha $\left.^{-1}\right), \mathrm{T}_{9}-(@ 25 \% \mathrm{RDF}$ + Rice straw @ 2.5 tha $^{-1}+$ Poultry Manure @ 2.5 tha $^{-1}$ + PSB@1 $\mathrm{kg} \mathrm{ha}^{-1}$ ) the fertilizers, organic manures and biofertilizer are applied in each plot according to treatment combinations. the seedlings was given to each plot in equal quantity based on general requirement and fertilizer doses are calculated and applied in each plot. The general recommended dose of NPK is 120:60:60. Methods which are used to analyse soil physical and chemical parameters given in table.

Organic manures are taken in this field experiment and they having different nutrient compositions they are discussed below

\section{Results and Discussion}

As depicted data presented in table 4 showed that the maximum bulk density was observed in the treatment combination $\mathrm{T}_{1}-($ @ absolute 
control) there was non-significant variation between various treatment combinations there was a non-significant effect on bulk density and solid space.in case of soil properties there was a significant effect on water holding capacity and a non-significant effect on soil $\mathrm{pH}$ and soil EC by different treatment combinations. But in case of plots treated with organic manures showed slight increasing in $\mathrm{pH}$ and EC. There was a significant difference between treatment combinations in the case of organic carbon. the maximum organic carbon content water holding capacity available nitrogen and available potassium $(0.72 \%, 375.94$ and $187.25 \mathrm{~kg} \mathrm{ha}^{-1}$ ) was recorded in the treatment combination $\mathrm{T}_{7}-(@ 50 \% \mathrm{RDF}+$ Poultry manure @ $5 \mathrm{t} \mathrm{ha}^{-1}$ ) but the maximum available Phosphorus in soil (45.72 $\mathrm{kg} \mathrm{ha}^{-1}$ ) was recorded in the treatment combination $\mathrm{T}_{9}$-(@25\% RDF + Rice straw@ 2.5 tha $^{-1}+$ Poultry Manure@2.5 tha ${ }^{-1}+$ PSB @ 1kgha $\left.{ }^{1}\right) . \mathrm{T}_{9^{-}}$(@25\% RDF + Rice straw @ $2.5 \mathrm{tha}^{-1}$ + Poultry Manure@2.5 t ha ${ }^{-1}+$ PSB @ 1kg $\mathrm{ha}^{-1}$ ) is noticed as second best treatment after $\mathrm{T}_{7^{-}}$(@50\% RDF + Poultry manure @ $5 \mathrm{t} \mathrm{ha}^{-}$ $\left.{ }^{1}\right)$ when compared with treatment combination $\mathrm{T}_{1-}$ (@ absolute control) similar findings had been reported by Ayalew and Dejene (2012) stated that integrated nutrient management is the best approach to supply adequate and balanced nutrients and increase crop productivity in an efficient and environmentally benign manner, without sacrificing soil productivity of future generations.it is also found that byHassan Shokri Vahed and Fatemeh Heydarnezhad (2012) Nandinidevi (2013), the maximum P uptake was noted when $75 \%$ RDF with vermicompost at the rate of $1 \mathrm{tha}^{-1}$ and PSB followed by the integration of $75 \%$ RDF with vermicompost at the rate of $1 \mathrm{t} \mathrm{ha}^{-1}$ (Fig. 1-4 and Table 1-7).

Table.1 List of soil physical parameters and methods used to analyse

\begin{tabular}{|c|l|l|}
\hline S. No. & Particulars & Method used Scientist Year \\
\hline $\mathbf{1}$ & Particle Density $\left(\mathrm{Mg} \mathrm{m}^{-3}\right)$ & Graduated cylinder method Muthuaval et al., 1992 \\
\hline $\mathbf{2}$ & Bulk Density $\left(\mathrm{Mg} \mathrm{m}^{-3}\right)$ & Graduated cylinder method Muthuaval et al.,1992 \\
\hline $\mathbf{3}$ & Pore space $(\%)$ & Graduated cylinder method Muthuaval et al., 1992 \\
\hline $\mathbf{4}$ & Water Holding capacity & Graduated cylinder method Muthuaval et al., 1992 \\
\hline $\mathbf{5}$ & Soil texture & Bouyoucos hydrometer method G JBouyoucos1927 \\
\hline $\mathbf{6}$ & Soil colour & Munsell colour chart method Albert H Munsell1905 \\
\hline
\end{tabular}

Table.2 List of soil chemical parameters and methods used to analyse

\begin{tabular}{|c|c|c|}
\hline S. No. & Particulars & Method used Scientist Year \\
\hline 1 & $\mathrm{pH}(1: 2)$ & Glass Electrode $\mathrm{pH}$ Meter Jackson1954 \\
\hline 2 & $\mathrm{EC}\left(\mathrm{dS} \mathrm{m} \mathrm{m}^{-1}\right.$ at $\left.25^{\circ} \mathrm{C}\right)$ & Conductivity Bridge Meter Wilcox 1950 \\
\hline 3 & Organic carbon (\%) & Wet-oxidation method Walkley and Blackman 1947 \\
\hline 4 & Available $\mathrm{N}\left(\mathrm{kgha}^{-1}\right)$ & $\begin{array}{l}\text { Alkaline Permanganate Method Subbiah and Asija } \\
1956\end{array}$ \\
\hline 5 & Available P $\left(\mathrm{kgha}^{-1}\right)$ & Olsen's Method Olsen et al., 1954 \\
\hline 6 & Available $\mathrm{K}\left(\mathrm{kg} \mathrm{ha}^{-1}\right)$ & Flame Photometer Method Toth and Prince1949 \\
\hline
\end{tabular}

Source:(Jaiswal 2006) 
Table. 3 List of nitrogen, phosphorus and potassium composition in different organic materials

\begin{tabular}{lcc}
\hline S. No. & Name of material & $\mathbf{N}: \mathbf{P}: \mathbf{K}(\boldsymbol{\%})$ \\
\hline 1. & Poultry manure (PM) & $3.03: 2.63: 1.40$ \\
2. & Rice straw (RS) & $0.80: 0.40: 0.30$ \\
3. & Vermicompost (VC) & $3.00: 1.00: 1.50$ \\
4. & Farm yard manure (FYM) & $0.50: 0.20: 0.50$ \\
\hline
\end{tabular}

Source:(Reddy andReddy2016)

Table.4 Interaction effect of integrated nutrient on bulk density particle density and moisture content of the soil in Rice Var:Bpt-5204

\begin{tabular}{|c|c|c|c|}
\hline Treatment & $\begin{array}{l}\text { Bulk density } \\
\left(\mathrm{Mg} \mathrm{m}^{-3}\right)\end{array}$ & $\begin{array}{l}\text { Particle density } \\
\qquad\left(\mathrm{Mg} \mathrm{m}^{-3}\right)\end{array}$ & $\begin{array}{l}\text { Pore space } \\
(\%)\end{array}$ \\
\hline $\mathrm{T}_{1^{-}}[((@$ absolute control] & 1.28 & 2.74 & 56.39 \\
\hline $\mathrm{T}_{2^{-}}[@ 100 \% \mathrm{RDF}]$ & 1.06 & 2.50 & 59.31 \\
\hline $\mathrm{T}_{3^{-}}\left[\left(@ 50 \% \mathrm{RDF}+\mathrm{FYM} @ 5 \mathrm{tha}^{-1}\right]\right.$ & 1.12 & 2.78 & 57.92 \\
\hline $\mathrm{T}_{4^{-}}\left[@ 50 \% \mathrm{RDF}+\right.$ Vermicompost @ $\left.5 \mathrm{t} \mathrm{ha}^{-1}\right]$ & 1.11 & 2.85 & 61.77 \\
\hline $\mathrm{T}_{5^{-}}\left[\right.$@ 50\% RDF + Rice straw @ $\left.5 \mathrm{t} \mathrm{ha}^{-1}\right]$ & 1.05 & 2.78 & 62.47 \\
\hline \multicolumn{4}{|l|}{ +FYM@2.5 t ha ${ }^{-1}+$ Rice Straw @ 2.5 tha $\left.^{-1}\right]$} \\
\hline $\mathrm{T}_{7^{-}}\left[\left(@ 50 \% \mathrm{RDF}+\right.\right.$ Poultry manure @ $\left.5 \mathrm{t} \mathrm{ha}^{-1}\right]$ & 1.05 & 2.57 & 54.73 \\
\hline \multicolumn{4}{|l|}{ @ $1 \mathrm{Kg} \mathrm{ha}^{-1}+$ Vermicompost @ $\left.2.5 \mathrm{tha}^{-1}\right]$} \\
\hline $\begin{array}{l}\mathrm{T}_{9^{-}}\left[\left(@ 25 \% \mathrm{RDF}+\text { Rice straw @ } 2.5 \mathrm{t} \mathrm{ha}^{-1}+\right.\right. \\
\text { Poultry Manure @ } 2.5 \mathrm{tha}^{-1}+\mathrm{PSB} @ 1 \mathrm{~kg}\end{array}$ & 1.24 & 2.50 & 55.97 \\
\hline f-test & NS & $S$ & NS \\
\hline S.Em. $( \pm)$ & - & 0.064 & - \\
\hline $\mathrm{CD}$ at $5 \%$ & - & 0.192 & - \\
\hline
\end{tabular}


Table.5 Interaction effect of integrated nutrient on solid space, specific gravity and water holding capacity of the soil in Rice Var:Bpt-5204

\begin{tabular}{|c|c|c|c|}
\hline Treatment & pace Speci & $\begin{array}{l}\text { gravity } \\
\mathrm{m}^{-3} \text { ) }\end{array}$ & $\begin{array}{l}\text { Water holding capacity } \\
(\%)\end{array}$ \\
\hline$\overline{\mathrm{T}_{1^{-}}[((@ \text { absolute control }]}$ & 42.27 & 2.58 & 65.38 \\
\hline $\mathrm{T}_{2^{-}}[@ 100 \% \mathrm{RDF}]$ & 39.61 & 2.29 & 60.89 \\
\hline $\mathrm{T}_{3^{-}}\left[\left(\right.\right.$@ $\left.50 \% \mathrm{RDF}+\mathrm{FYM} @ 5 \mathrm{t} \mathrm{ha}^{-1}\right]$ & 40.74 & 2.43 & 67.45 \\
\hline $\mathrm{T}_{4}-\left[\right.$ [ $90 \% \mathrm{RDF}+$ Vermicompost @ $\left.5 \mathrm{t} \mathrm{ha}^{-1}\right]$ & 39.6 & 2.24 & 66.38 \\
\hline $\mathrm{T}_{5^{-}}\left[\right.$@ 50\% RDF+Rice straw @ $\left.5 \mathrm{tha}^{-1}\right]$ & 36.78 & 2.58 & 61.14 \\
\hline $\begin{array}{l}\mathrm{T}_{6} \text { - } @ 25 \% \mathrm{RDF}+\text { Vermicompost @2.5 } \mathrm{tha}^{-1} \\
\text { + FYM @2.5 } \mathrm{tha}^{-1}+\text { Rice Straw @2.5 tha }{ }^{-1}\end{array}$ & 38.54 & 2.36 & 65.72 \\
\hline $\mathrm{T}_{7^{-}}\left[\left(@ 50 \% \mathrm{RDF}+\right.\right.$ Poultry manure @ $\left.5 \mathrm{t} \mathrm{ha}^{-1}\right]$ & 43.6 & 2.37 & 62.78 \\
\hline $\begin{array}{l}\mathrm{T}_{8^{-}}\left[\left(@ 25 \% \mathrm{RDF}+\mathrm{FYM} @ 2.5 \mathrm{t} \mathrm{ha}^{-1}+\mathrm{PSB}\right.\right. \\
\left.@ 1 \mathrm{Kg} \mathrm{ha}^{-1}+\text { Vermicompost @ } 2.5 \mathrm{t} \mathrm{ha}^{-1}\right]\end{array}$ & 39.28 & 2.31 & 63.39 \\
\hline $\begin{array}{l}\mathrm{T}_{9^{-}}\left[\left(@ @ 25 \% \mathrm{RDF}+\text { Rice straw @ } 2.5 \mathrm{tha}^{-1}+\right.\right. \\
\left.\quad \text { Poultry Manure @ } 2.5 \mathrm{t} \mathrm{ha}^{-1}+\mathrm{PSB} @ 1 \mathrm{~kg} \mathrm{ha}^{-1}\right]\end{array}$ & 43.36 & 2.14 & 62.03 \\
\hline f-test & NS & NS & $\mathrm{S}$ \\
\hline S.Em. $( \pm)$ & 1.172941 & - & 0.594087 \\
\hline $\mathrm{CD}$ at $5 \%$ & 3.516476 & - & 1.781073 \\
\hline
\end{tabular}

Table.6 Interaction effect of integrated nutrient on soil $\mathrm{pH}$, electrical conductivity and organic carbonin Rice Var:Bpt-5204

\begin{tabular}{|c|c|c|c|}
\hline Treatment & pH & $E C\left(d S ~ m^{-1}\right)$ & $\mathrm{OC}(\%)$ \\
\hline$\overline{\mathrm{T}_{1^{-}}[(\text {@ absolute control }]}$ & 7.33 & 0.036 & 0.50 \\
\hline $\mathrm{T}_{2^{-}}[@ 100 \% \mathrm{RDF}]$ & 7.68 & 0.033 & 0.61 \\
\hline $\mathrm{T}_{3^{-}}\left[\left(@ 50 \% \mathrm{RDF}+\mathrm{FYM} @ 5 \mathrm{tha}^{-1}\right]\right.$ & 7.72 & 0.033 & 0.69 \\
\hline $\mathrm{T}_{4^{-}}\left[@\right.$ @50\% RDF + Vermicompost @ $\left.5 \mathrm{tha}^{-1}\right]$ & 7.64 & 0.036 & 0.65 \\
\hline $\mathrm{T}_{5^{-}}\left[@ 50 \% \mathrm{RDF}+\right.$ Rice straw @ $\left.5 \mathrm{t} \mathrm{ha}^{-1}\right]$ & 7.69 & 0.033 & 0.63 \\
\hline $\begin{array}{l}\mathrm{T}_{6^{-}}\left[\text {@ 25\% RDF + Vermicompost @ 2.5 } \mathrm{tha}^{-}\right. \\
\left.\quad+\text { FYM @2.5 tha-1 + Rice Straw @ } 2.5 \mathrm{t} \mathrm{ha}^{-1}\right]\end{array}$ & 7.74 & 0.036 & 0.62 \\
\hline $\mathrm{T}_{7^{-}}\left[\left(@ 50 \% \mathrm{RDF}+\right.\right.$ Poultry manure @ $\left.5 \mathrm{t} \mathrm{ha}^{-1}\right]$ & 7.67 & 0.036 & 0.72 \\
\hline $\begin{array}{l}\mathrm{T}_{8^{-}}\left[\left(@ 25 \% \mathrm{RDF}+\mathrm{FYM} @ 2.5 \mathrm{t} \mathrm{ha}^{-1}+\mathrm{PSB}\right.\right. \\
\left.@ 1 \mathrm{Kg} \mathrm{ha}^{-1}+\text { Vermicompost @ } 2.5 \mathrm{t} \mathrm{ha}^{-1}\right]\end{array}$ & 7.73 & 0.033 & 0.69 \\
\hline $\begin{array}{l}\mathrm{T}_{9^{-}}\left[\left(@ 25 \% \mathrm{RDF}+\text { Rice straw @ } 2.5 \mathrm{tha}^{-1}+\right.\right. \\
\left.\quad \text { Poultry Manure @ } 2.5 \mathrm{t} \mathrm{ha}^{-1}+\mathrm{PSB} @ 1 \mathrm{~kg} \mathrm{ha}^{-1}\right]\end{array}$ & 7.69 & 0.036 & 0.62 \\
\hline$\overline{\text { f-test }}$ & NS & NS & $\mathrm{S}$ \\
\hline S.Em. $\left.{ }_{ \pm}\right)$ & - & - & 0.030 \\
\hline $\mathrm{CD}$ at $5 \%$ & - & & \\
\hline
\end{tabular}


Table.7 Interaction effect of integrated nutrient on available nitrogen, phosphorus and potassium of the soil in RiceVar:Bpt-5204

\begin{tabular}{|c|c|c|c|}
\hline Treatments & $\begin{array}{c}\mathrm{N} \\
\left(\mathrm{kg} \mathrm{ha}^{-1}\right)\end{array}$ & $\begin{array}{c}\mathrm{P}_{2} \mathrm{O}_{5} \\
\left(\mathrm{~kg} \mathrm{ha}^{-1}\right)\end{array}$ & $\begin{array}{c}\mathrm{K}_{2} \mathrm{O} \\
\left(\mathrm{kg} \mathrm{ha}^{-1}\right)\end{array}$ \\
\hline$\overline{\mathrm{T}_{1^{-}}[((@ \text { absolute control }]}$ & 224.80 & 24.13 & 139.42 \\
\hline $\mathrm{T}_{2^{-}}[@ 100 \% \mathrm{RDF}]$ & 330.83 & 43.70 & 188.31 \\
\hline $\mathrm{T}_{3^{-}}\left[\left(@ 50 \% \mathrm{RDF}+\mathrm{FYM} @ 5 \mathrm{tha}^{-1}\right]\right.$ & 337.85 & 29.48 & 149.86 \\
\hline $\mathrm{T}_{4^{-}}\left[@ 50 \% \mathrm{RDF}+\right.$ Vermicompost @ $\left.5 \mathrm{t} \mathrm{ha}^{-1}\right]$ & 325.75 & 35.50 & 176.89 \\
\hline $\mathrm{T}_{5^{-}}\left[@ 50 \% \mathrm{RDF}+\right.$ Rice straw @ $\left.5 \mathrm{t} \mathrm{ha}^{-1}\right]$ & 329.03 & 37.32 & 149.86 \\
\hline $\begin{aligned} \mathrm{T}_{6^{-}} & {\left[@ 25 \% \mathrm{RDF}+\text { Vermicompost @ } 2.5 \mathrm{tha}^{-1}\right.} \\
& \left.+\mathrm{FYM} @ 2.5 \mathrm{t} \mathrm{ha}^{-1}+\text { Rice Straw @ } 2.5 \mathrm{t} \mathrm{ha}^{-1}\right]\end{aligned}$ & 341.75 & 41.26 & 149.86 \\
\hline $\mathrm{T}_{7^{-}}\left[\left(@ 50 \% \mathrm{RDF}+\right.\right.$ Poultry manure @ $\left.5 \mathrm{t} \mathrm{ha}^{-1}\right]$ & 375.94 & 39.67 & 187.25 \\
\hline $\begin{array}{r}\mathrm{T}_{8-}\left[\left(@ 25 \% \mathrm{RDF}+\mathrm{FYM} @ 2.5 \mathrm{tha}^{-1}+\mathrm{PSB}\right.\right. \\
\left.@ 1 \mathrm{Kg} \mathrm{ha}^{-1}+\text { Vermicompost @ } 2.5 \mathrm{t} \mathrm{ha}^{-1}\right]\end{array}$ & 350.60 & 35.55 & 176.94 \\
\hline $\begin{array}{l}\mathrm{T}_{9^{-}}\left[\left(@ 25 \% \mathrm{RDF}+\text { Rice straw @ } 2.5 \mathrm{t} \mathrm{ha}^{-1}+\right.\right. \\
\left.\text { Poultry Manure @ } 2.5 \mathrm{tha}^{-1}+\mathrm{PSB} @ 1 \mathrm{~kg} \mathrm{ha}^{-1}\right]\end{array}$ & 355.65 & 45.72 & 176.89 \\
\hline f-test & $\mathrm{S}$ & $\mathrm{S}$ & $\mathrm{S}$ \\
\hline S.Em. $( \pm)$ & 1.534 & 0.322 & 1.510 \\
\hline $\mathrm{CD}$ at $5 \%$ & 4.598 & 0.968 & 4.527 \\
\hline
\end{tabular}

Fig.1 Interaction effect of integrated nutrient on soil bulk density, particle density and pore space in Rice Var:Bpt-5204

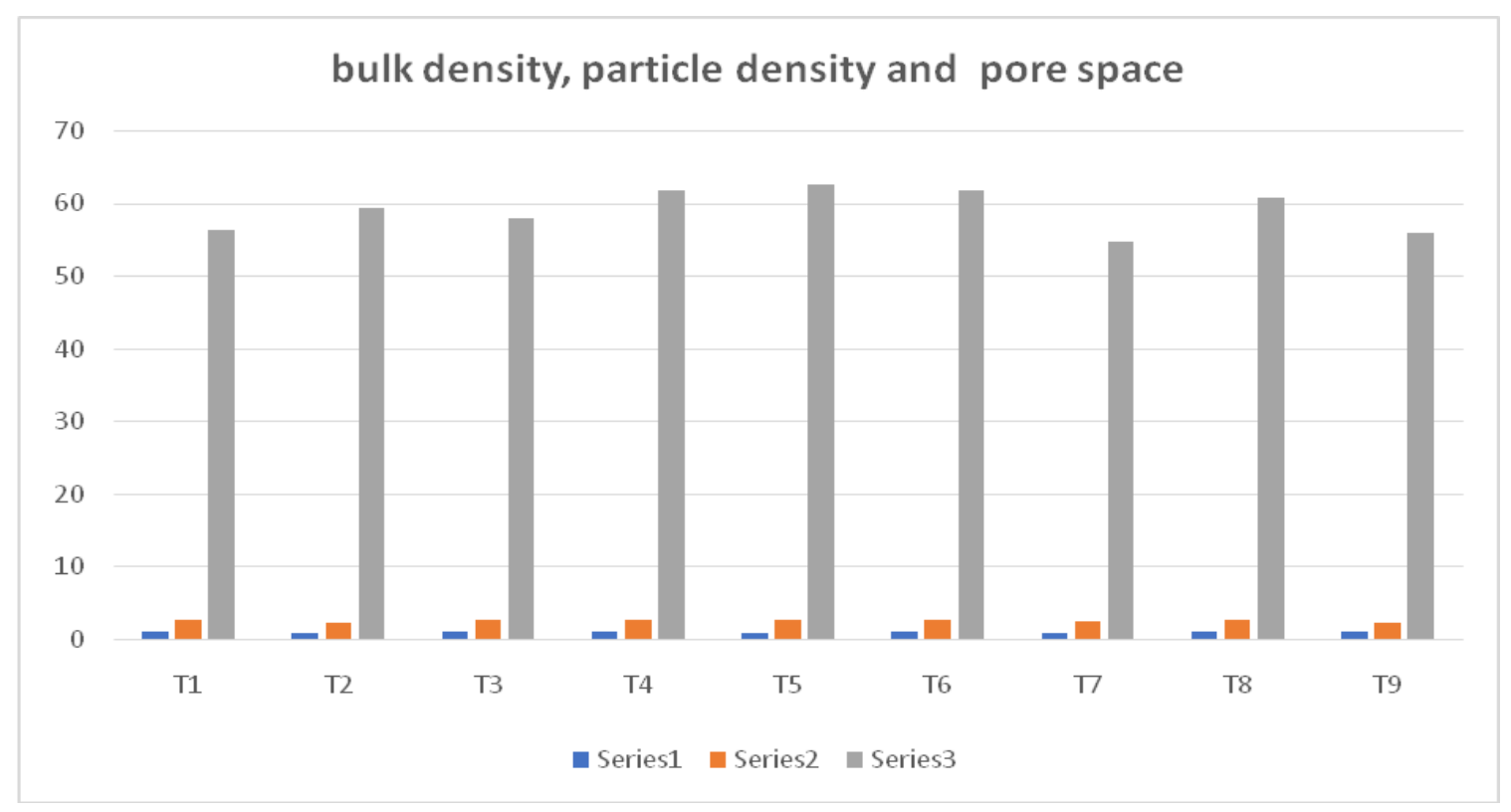


Fig.2 Interaction effect of integrated nutrient on solid space, water retaining capacity and specific gravity of soil in RiceVar:Bpt-5204

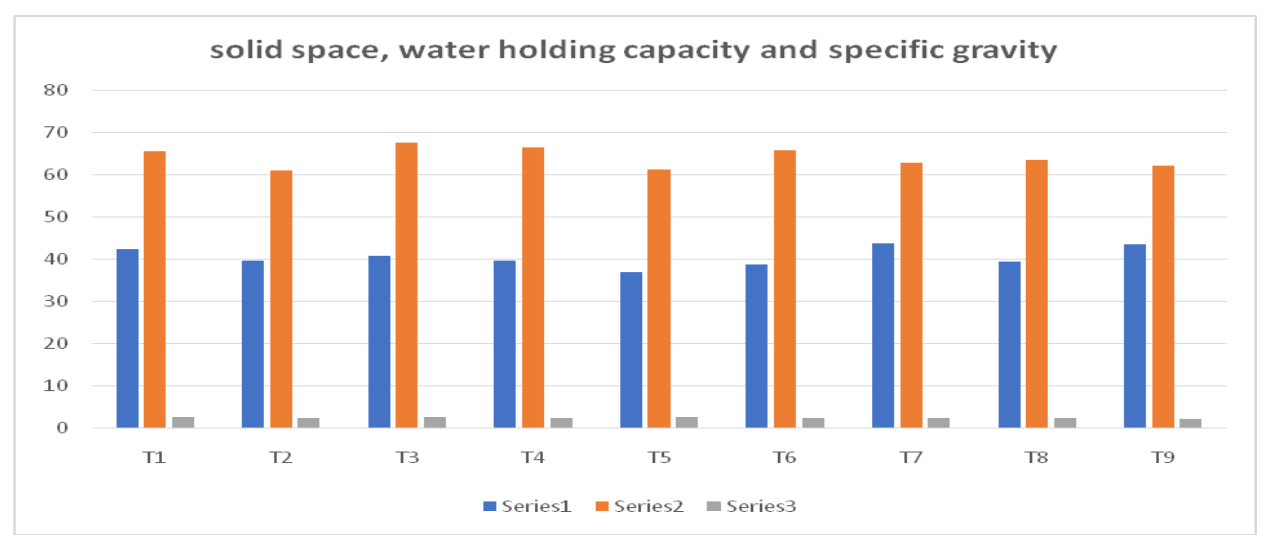

Fig.3 Interaction effect of integrated nutrienton soil $\mathrm{pH}$,electrical conductivity andorganic carbon in RiceVar:Bpt-5204

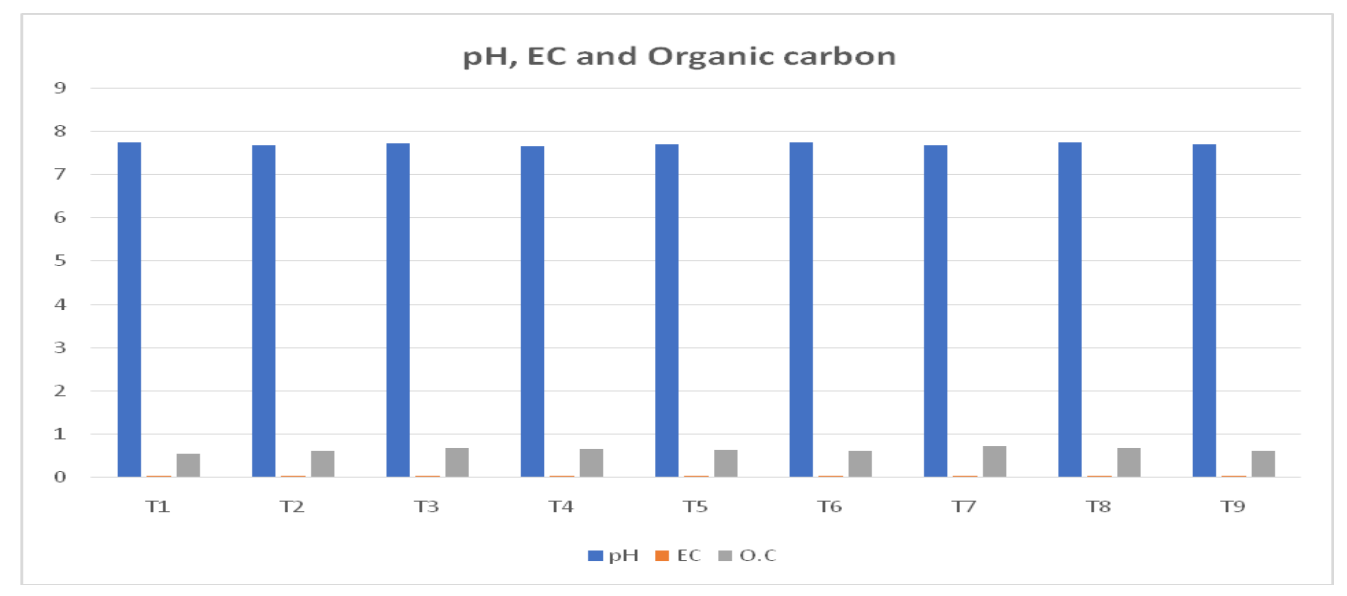

Fig.4 Interaction effect of integrated nutrient on available nitrogen, phosphorus and potassium of soil in RiceVar:Bpt-5204

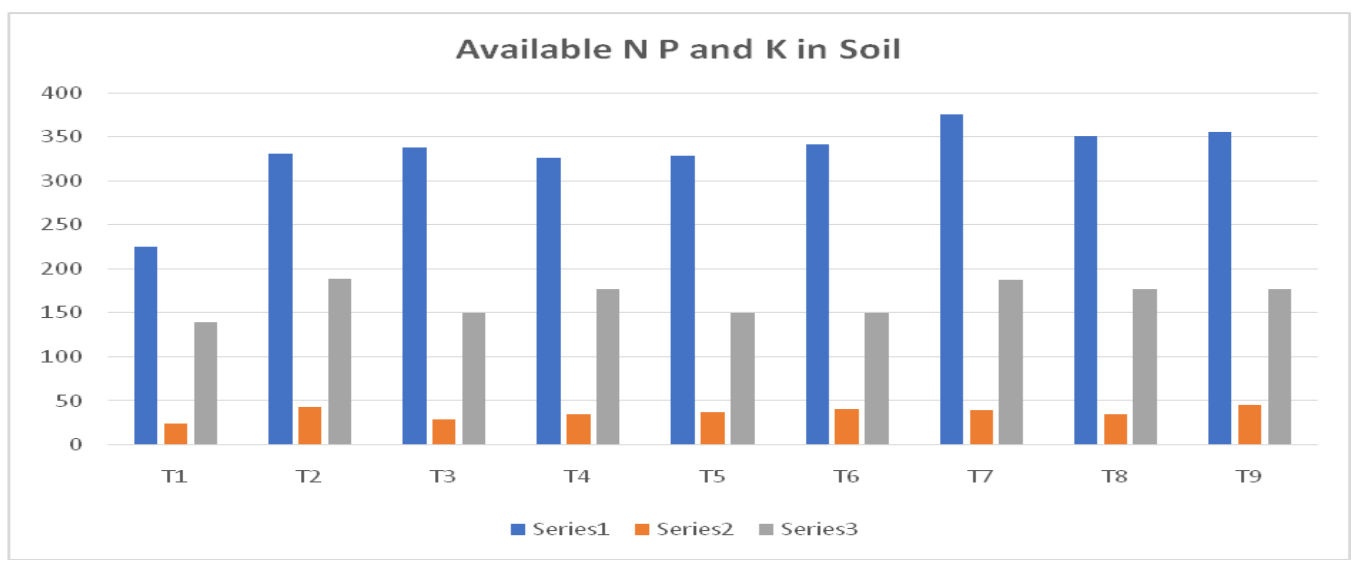


The treatments were allocated in a randomized block design with three replications. the treatments consisted of combination of different levels of NPK, organic manures and a bio-fertilizer. the crop was transplanted on $20^{\text {th }}$ July 2019 with a seed rate of $25 \mathrm{~kg} \mathrm{ha}^{-1}$ and harvested on $13^{\text {th }}$ November 2019.The observation taken on different plant characters during the crop growth period and at crop harvest. in the terms of soil quality parameters like soil organic carbon content, available NPK, $\mathrm{pH}$, $\mathrm{EC}$ and growth parameters like plant height number of tillers panicle length number of seeds per panicle grain yield Straw yield of Rice etc., treatment combination $\mathrm{T}_{7}-[@ 50 \%$ RDF + Poultry manure @ $\left.5 \mathrm{t} \mathrm{ha}^{-1}\right]$ showing the better result from the economical point of view the same treatment combination gave the maximum profit of Rs. 77,708.00 Rs.ha ${ }^{-1}$ with $\mathrm{C}: \mathrm{B}$ ratio of $1: 3.03$ and it was very closely followed $\mathrm{T}_{9}$-[@25\% RDF + Rice straw@2.5 t ha ${ }^{-1}+$ Poultry Manure @ $2.5 \mathrm{t}$ $\mathrm{ha}^{-1}+$ PSB @ $\left.1 \mathrm{~kg} \mathrm{ha}^{-1}\right]$ as they compared with treatment combination $\mathrm{T}_{1}-(@$ absolute control). Poultry manure supplies continuous slow release organic matter and increased more available nutrients, which aided in better growth parameters of Rice.

It was concluded from the trail the treatment $\mathrm{T}_{7}$ [ $@ 50 \% \mathrm{RDF}+$ Poultry manure @ $\left.5 \mathrm{t} \mathrm{ha}^{-1}\right]$ particularly poultry manure @ $5 \mathrm{t} \mathrm{ha}^{-1}$ in combination with @ 50\% RDF from inorganic sources was given the significant results and this combination gave the better soil health parameters and yield than the inorganic fertilizers alone.

\section{Acknowledgement}

The author is thankful to Hon'ble Vice Chancellor, HOD, Advisor and non-teaching staff of department of Soil Science and Agricultural Chemistry, Sam Higginbottom University of Agriculture, Technology and
Sciences, Prayagraj Uttar Pradesh for providing all necessary facilities and clarify studies.

\section{References}

Ayalew A., and Dejene T. (2012) Combined application of organic and inorganic fertilizers to increase yield of barley and improve soil properties at freeze in southern Ethiopia. Innovative Systems Design and Engineering 3(1): 25-35.

Ali, M., Islam, M. and Jahir Uddin M. (2009) Effect of integrated use of organic manures with chemical fertilizers in the rice-rice cropping system and its impact on soil health. Bangladesh Journal of Agricultural Research., 34(1): 81-90.

Dubey R., Sharma R.S. and Dubey D.P. (2014) Effect of Organic, Inorganic and Integrated Nutrient Management on Crop Productivity, Water Productivity and Soil Properties under Various Rice-Based Cropping Systems in Madhya Pradesh, India. International Journal of Current Microbiology and Applied Sciences, 3(2): 381-389.

Economics Time (2019) India's 2019-2020 food grain production to hit a record high of 291.95 million tonnes, the economic times, ET bureau, pub. on 18 February 2020, 05:27 PM IST.

FAO (2017) Food and agricultural organisations of the united nations rice monitor volume XXI ISSUE No-1, pub. April 2018.

Gopal Krishna Tiwari A (2019) Statistical Study of Trends of Rice-Wheat Production on Districts of Western U.P., India International Journal of Current Microbiology and Applied Sciences ISSN: 2319-7706 Volume 8 Number 06 (2019)8:(6). 
Gopi Potupureddi et al., (2017) Identification of Agro-Morphological characters in Sheath blight Tolerant lines of Samba Mahsuri (BPT-5204) Rice variety. Bulletin of Environment, Pharmacology and Life Sciences Bull. Env. Pharmacology and Life Science Vol 6[10] September 2017: 41-45.

Gill J.S. and Walia S. S.(2014) Influence of FYM, Brown Manuring and Nitrogen levels on Direct Seeded and Transplanted Rice (Oryza sativa L.) A review. Research Journal of Agriculture and Environmental Management. Vol. 3(9), pp. 417-426.

Hassan Shokri Vahed and Fatemeh Heydarnezhad (2012) Performance of phosphate solubilizing bacteria for improving growth and yield of rice (Oryza sativa L.) in the presence of phosphorus fertilizer. International Journal of Agriculture and Crop Sciences. 4 (17):1228-1232.

L.K. Baishya and S.S. Rathore (2014) Effect of Integrated Nutrient Management on Rice Productivity, Profitability And Soil Fertility, Annals of Plant and Soil Research 17 (1):86-90 (2015).

Larijani B. A. and Hoseini S.J. (2012) Comparison of Integrated Chemical and Organic Fertilizer Management on
Rice Growth and Yield under System of Rice Intensification (SRI). International journal of Agronomy and Plant Production. Vol. 3 (S): pp.726731.

Nandini Devi (2013) Influence of inorganic, biological and organic manures on nodulation and yield of soybean (Glycine max) and soil properties. Australian Journal of CropScience 7(9): 1407-1415.

Jaiswal P. C. (2006) Soil, plant and water analysis manual, chapter soil analysis, Kalyani publishers, Ludhiana-141 008, pg. No. 172-196.

Swaminathan M.S. (2002) Green revolution is now greed revolution. The Hindu, date.02.08.2002, pp.5.

Yellamanda Reddy T. and G H Sankara Reddy (2016) principles of agronomy, chapter-9 Mineral nutrition, manures and fertilizers, Kalyani publishers Ludhiana-141008, Pg. No 279-284.

Udhayakumar K. and Ramasamy (2016) Performance of rice varieties under sustainable organic nutrient management practices on dry matter production, grain and straw yield, harvest index of rice (Oryza sativa L.). Life Sciences Leaf lets., 71:48-55.

\section{How to cite this article:}

Dudekula Sarmas Vali, Arun Alfred David, Narendra Swaroop and Tarence Thomas. 2020. Efficiency of Integrated Nutrient Management to Improve Soil Health Growth Parameters and Yield Attributes of Rice (Oryza sativa L.) Var: Bpt-5204. Int.J.Curr.Microbiol.App.Sci. 9(10): 2452-2460. doi: https://doi.org/10.20546/ijcmas.2020.910.293 